\title{
FIXED TRAJECTORIES: RACE, SCHOOLING, AND GRADUATION FROM A SOUTHERN ONTARIO UNIVERSTTY
}

\author{
CARLE. JAMES \\ YORK UNIVERSITY
}

\author{
GLLLIAN PAREKH \\ YORK UNIVERSITY
}

\begin{abstract}
According to Statistics Canada, during this decade (2019-2028) about $75 \%$ of new jobs will require a post-secondary education (Government of Canada, 2017). This study explores a unique dataset that follows students $(n=11,417)$ from a large urban school district to a local university in Southern Ontario. Using both descriptive statistics and a binary logistic regression and a framework of categorical inequality (Domina et al., 2017), we examine the academic trajectories of students-particularly of Black students. Findings show that, compared to their peers, neither high school nor university programs provide Black students with the kinds of educational experiences needed for university graduation and academic success that would enable them to realize their fullest social and economic potentials.
\end{abstract}

Keywords: Black students, university graduation, categorical inequality, secondary programming, university pathways, student demographics

\section{Résumé}

Selon Statistique Canada, au cours de la présente décennie (2019-2028), environ soixante-quinze pour cent des nouveaux emplois nécessiteront une formation postsecondaire (Gouvernement du Canada, 2017). Cette étude explore un ensemble de données unique qui suit les étudiants ( $n=11417$ étudiants) d'un grand district scolaire urbain jusqu'à une université locale du sud de l'Ontario. En utilisant à la fois des statistiques descriptives et une régression logistique binaire et un cadre d'inégalité catégorielle (Domina et al., 2017), nous examinons le parcours éducatif des étudiants, en particulier des étudiants noirs. Les résultats démontrent que, par rapport à leurs pairs, ni les programmes d'études secondaires ni ceux du niveau universitaire n'offrent aux étudiants noirs les types d'expériences éducatives nécessaires à l'obtention d'un diplôme universitaire et à la réussite scolaire qui leur permettraient de réaliser pleinement leur potentiel social et économique.

Mots-clés : Étudiants noirs, diplomation universitaire, inégalité catégorielle, programmes d'enseignement secondaire, parcours universitaires, démographie étudiante

\section{Introduction}

Due to the increase in high skills occupations during the decade $2019-2028,75 \%$ of all new jobs are expected to require a post-secondary education (Government of Canada, 2017). Including apprenticeship and/or trades diplomas/certificates, just over $60 \%$ of Canadians have completed a diploma or degree at the post-secondary level (Statistics Canada, 2021). And insofar as not all ethnoracial groups have equitable access to post-sec- ondary education, which is recognized as "one of the most influential and instrumental tools available to society" (Serna \& Woulfe, 2017, p. 3), it is important to establish who attends, or has attended, colleges and/or universities, and therefore are able to maximize access to job opportunities. Research has shown that factors such as race, gender, school readiness, academic program, educational guidance, proximity to post-secondary institutions, support systems, and discriminatory practices help to shape and determine schooling opportunities 
and educational trajectories of students (James \& Turner, 2017; Parekh, 2013; Parekh, et al., 2020; Strayhorn, 2017). Furthermore, apart from attending post-secondary institutions, what role might demographic characteristics and secondary school programs play in university attendance and successful graduation of students?

In this article, we explore the educational trajectories of students from public school through to graduation from a university in southern Ontario. Specifically, using self-reported racial identity data of students, we explore the relationships between students' high school program of study, their high school-to-university pathway (direct and indirect), and their graduation from university. We give special attention to the schooling patterns of Black students noting how they compare with other racialized and white students. Our discussion is framed by categorical inequality (Domina et al., 2017) and social reproduction theories (Bourdieu, 1973; Giroux, 2013) as well as QuantCrit approaches to data analysis (Gillborn et al., 2018). Each of these frameworks draws attention to the ways in which the inescapable dominant ideology of neoliberalism, structured on whiteness, drives the policies and practices of educational institutions, and in turn, shapes the social and educational experiences, participations, aspirations and outcomes of individuals (Giroux, 2014; Leonardo \& Broderick, 2011; Mirowski, 2013). Furthermore, in the context of neoliberalism, the pattern of stratification is exacerbated, due in part to societal inequity, and concomitantly racism and discrimination (Thomas, 2010), and as such, will have differential effect on students, and most significantly on some racialized students.

In what follows, we explain the data gathering process, followed by the presentation of the quantitative data of students' pathways to university graduation, and a discussion of what our findings help to explain about the educational trajectory of students, and Black students in particular. But before doing so, in the next section, we discuss the theorical framework.

\section{Theoretical Scaffolds: Categorical Inequality and Social Reproduction}

Categorical inequality takes as given the inequitable structure of society and the important role that schools play in maintaining it. The institutional processes of schools create categories into which individuals are sorted, and in doing so, "generate and reinforce social inequalities" (Domina et al., 2017, p. 312). Domina et al. (2017) also argue that:

Even if schools perfectly compensate for racial, ethnic, gender, or class inequalities among their students, they would still structure and legitimate social inequalities in schooled societies. One way in which schools structure inequality is by issuing a status-differentiated set of educational credentials that interact with labor markets and other social systems to influence individuals' placements in contemporary systems of social stratification. (pp. 313-314)

The fact is, schooling opportunities, allocation of educational resources, teacher assessments, the academic tracks or programs into which students select or are placed, learning incentives, exposure to post-secondary possibilities (such as university), class, gender and racial categorized meanings, high-stakes testing, and of course, grades (a subjective measure)-are all part of the schooling processes that students (and their families) must navigate and negotiate in their pursuit of education (James, 2019; Lewis-McCoy, 2014; Sleeter \& Grant, 2011; Tzanakis, 2011). It is essential to approach the interrelationship of race and schooling through an intersectional lens. Intersectionality, as developed by Crenshaw (1989), argues that no one singular identity trait can account for a particular experience; but yet, the experience is often shaped by the intersection of identity characteristics. For example, the experience of Black students in university will differ across the intersection of students' racial, gender, disability, and class identities. Therefore, it is important when examining the experiences of Black students, that other factors, particularly sociodemographic identity and family characteristics, be considered as well.

In terms of race, researchers have long highlighted the ways in which schools re-inscribe "the racial meanings that shape students' understandings" (Domina et al., 2017, p. 318) of what is academically and socially possible for them in a society where white students enjoy social privileges or advantages relative to racialized students. Through teacher appraisals and instructional groupings, elementary schooling set students on an educational path that directs them into particular secondary schooling streams, which, in turn, can determine access to post-secondary institutions from which students grad- 
uate or do not graduate. Understanding that the early educational context initiates the path toward educational and life outcomes means that each educational institution plays a role in categorical inequalities to which students are subjected (Long et al., 2010).

A further explanatory theory that helps us understand the ways in which the schooling system produces and reproduces social and educational inequities is social reproduction theory, which purports that schools act as sorting mechanisms premised on capitalism resulting in class division and the perpetuation of unequal power hierarchies that benefit the wealthy and reinforce inequity (Macris, 2011; Serna \& Woulfe, 2017). And according to Collins (2009), social reproduction theory proffers that "schools are not institutions of equal opportunity but mechanisms for perpetuating social inequalities" ( $p$. 35). As such, schooling and educational attainment are considered to be strong determinants of individuals' social origin, status, privilege, and destination; and "thus a central element in the process of social reproduction" (Reichelt et al., 2019, p. 1324). But while there is compelling logic and evidence that point to how one's status in a stratified society might be reproduced, care must be taken not to be positivistic in applying social reproduction theory. It is imperative that consideration is given to the changes that take place over time, due in part to sociocultural contexts and the agency that individuals exercise. For as Gewirtz and Crib (2003) write, students should not only be considered "in relation to class divisions but in relation to a wider range of intersecting social axes including class, race, gender, sexuality, disability, and ability" (p. 244); and they actively engage "in making sense of their social conditions that are not of their own making" (p. 254). Essentially, taking a critical approach, social reproduction theory invites an interrogation of "the complex network of social processes and human relations that produce the conditions" of individuals' existence (Bhattacharya, 2017, p. 2).

In their article, "School tracking and its role in social reproduction: Reinforcing educational inheritance and the direct effects of social origin," Reichelt et al. (2019) contend that education-considered the foremost mediator of social reproduction-is differentially accessed and attained, which results in "educational stratification, ability grouping, sorting or differentiation" among students (p. 1326). The process of tracking or streaming-that is, the sorting of students according to ability and interest at different ages-fosters the allocation of students into educational environments that are homogeneous in terms of their cognitive abilities, interests, and backgrounds (Parekh, in press). Serna and Woulfe (2017) contend that social reproduction theory is generally used to examine students' access to and successes in higher education. It provides a means of understanding how students from marginalized and/or low income backgrounds are excluded from pursuing or attaining success in higher education. That exclusion is not a matter of personal choice as the ideology of neoliberalism holds-thereby downloading the choice of not pursuiting a university education onto individual students-but rather it is structured into educational system. In such cases, these young people's social capital, differential values, and social currency contribute to them staying away from post-secondary education, and as such "the educational system preserves and reinforces the division between the classes" (Serna \& Woulfe, 2017, p. 3). The homogeneity of the sociocultural background of university students tends to be made up, as Serna and Woulfe (2017) indicate, largely of individuals who can access the structures that are closely aligned with their cultural, economic, and linguistic capital. As such, Serna and Woulfe suggest that "it is these same power structures that arguably help some students feel much more at home on campus than others" (p. 3).

\section{The Education Pathways: From Elementary School through to University Graduation}

Research conducted in Canada, the United States, and Britain have long shown that the schooling system has failed Black students, thereby resulting in their poor educational performance and inequitable attainment (James, 2021; Lewis-McCoy, 2014; Livingstone et al., 2014; Vincent et al., 2013; Wright et al., in press). These studies have highlighted how streaming or tracking have consistently operated in structuring the educational trajectory of Black students-based on, among other factors, educators' perceptions of Black students as intellectually limited and disinterested in education. These perceptions contribute to these students being streamed into educational programs that are less likely to prepare them for post-secondary education. Yet, like all other parents, Black parents are just as likely to think that education, and more so, post-secondary education, 
will provide their children the opportunities needed to become socially and economically successful in the society (James, 2021; Vincent, 2017).

However, research continues to show that racial and class biases operate in the assessments that presume to test for the ill-defined notion of intelligence, as well as the cognitive and academic capacities of students (Ben-Moshe et al., 2014; Connor, 2017; Gould, 1996; Parekh et al., 2018), resulting in an over-representation of Black youth being placed in educational programs that limit their post-high school options. In the case of Ontario, for instance, beginning in Grade 9, students pursue various pathways through high school resulting in an array of post-high school opportunities. In Grade 9 , students have the option to pursue program streams such as Academic, which is designed to prepare them for university-level courses in Grades 11-12 and subsequently university; Applied, which is formulated to offer more "hands-on learning" and prepare students mostly for college level courses in Grades 11-12, and who upon graduation might enter college; or Locally Developed, which focuses on concrete or basic concepts expected to prepare students to enter directly into the world of work. These streams or pathways remain fairly distinct and contribute to the "educational stratification, ability grouping, sorting or differentiation" of students (Reichelt et al., 2019, p. 1326). Furthermore, evidence indicates that in Ontario racialized and poor children are more likely to be placed in Applied and Locally Developed school programs, making it difficult for them to pursue university education (Clandfield et al., 2014). Yet, proponents of the current academic structure consistently justify inequitable outcomes as based on students' choice and interests (Smaller, 2014).

That the streaming processes of schools sort, categorize, and organize students by perceived capacity to facilitate instruction and accommodate their needs, interests, and aspirations, as well as those of their parents, has significant implications for students' access and mobility through school, and particularly post-high school. Used as a sorting mechanism for the broader society, academic success or failure in school is considered to be based on merit and students' efforts. Duncan-Andrade and Morrell (2008) argue that poor academic performance or failure, despite identified inequities in schools, can be used by proponents of meritocratic social structures as justification for future economic inequality. Indeed, as Brantlinger (2006) writes in her chapter on "winners need losers," "such ideological [and meritocratic] persuasions lead people to believe that high achievers are entitled to rewards and low achievers deserve negative school and life outcomes" (Brantlinger, 2006, p. 202).

Gender plays a significant role in the prevailing perceptions of students' intellectual capacity and work ethic (Parekh et al., 2018); and in turn, their educational outcomes such as attendance at university and eventually graduating. In his study, "Factors that influence the persistence and success of Black men in urban public universities," Strayhorn (2017) found that a strong support system or network of peers, faculty, and staff; on-campus services such as counselling, writing, and tutoring; and the connection of the university to the surrounding community were important factors for the educational success of the Black males. This was particularly so for those students who were pursuing careers in the community or public sector because of their ambitions to give back to the community, especially communities with which they identified. And given their experiences with racism and discrimination, Black young men tended to rely on their peer support systems to assist them in negotiating school (Strayhorn, 2017). Further studies indicate that on-campus academic advising services and the time spent with advisors help to improve the educational experiences of Black male students (Johnson et al., 2019: Goings et al., 2017). For instance, in a case study of a 17-year old Black male college sophomore in the United Kingdom, it was shown that mentorship assisted him in his development of personal, social, academic, and professional growth, as well as his passion for learning, and hence his academic trajectory (Goings et al., 2017).

In the case of young women, McPherson's (2020) study found that unfair expections, differential treatment, and being excluded from valuable educational opportunities by teachers-all of which lead to unequal learning outcomes-are some of the problems Black female students experience in Greater Toronto Area schools. Participants noted that the way they were treated by teachers signaled the teachers' failure to grasp that not all students learn in the same way and as such, they would isolate and exclude Black female students from the learning process. This practice, in turn, justifies teachers' belief that Black girls are not interested in learning. In explaining their experiences with differential treatment in schools, one research pariticpant said: 
I feel like the White girls get some second chances. My assignment is late and the teacher tells us to tell her a week before if we are not going to finish the project. When it comes to the date and your project isn't done, they let White students come back next week and present it to the class. But other students, no. (McPherson, 2020, p. 12)

McPherson (2020) concludes by suggesting that the onus should not fall soley on Black young women to show their resilience in terms of being able to overcome the inequties in schools and claims that "education is one of the structures in which Black girls experience powerlessness, and therefore, they require specific attention and accommodations if they are to succeed within the system" (p. 17).

In approaching the issues pertaining to categorical inequality, we ask: Who accesses, attends, and eventually graduates from the university; and how, in particular, is the situation of Black students similar and different from that of their peers? And what role does secondary school programs of study play in the educational trajectories of students?

\section{Methodology}

For this study, we draw upon a unique dataset that merged students' demographic information, program of study, schooling climate, and educational outcomes from a large public K-12 School Board in Southern Ontario, Canada, to students' information at a large university in the area. The initial process of merging the school and university information resulted in a positive match for 26,443 students. To obtain the richest information, including student demographic information, we decided to look specifically at students in the 2003-2007 cohorts (students who started Grade 9 in those years and completed an extensive survey). This resulted in obtaining 11,417 student records for this study. For this analysis, we ran basic descriptive statistics as well as conducted a binary logistic regression.

We are cognizant of the fact that quantitative analysis has a history and reputation of serving institutional needs over those of the community (D'Ignazio \& Klein, 2020); and that attempting to distill the complexity of student identity and school experiences into fixed variables or categories can obscure the interrelated ways in which discrimination resulting from racism and ableism operates in relation to these factors (Gillborn et al., 2018). Hence, adopting the principles of QuantCrit, which recognizes that quantitative analysis is not neutral, but can be most effective when examining systems and not people, we take a critical orientation to examining the results we obtain in our effort toward advancing social justice (Gillborn et al., 2018).

\section{Variable Categories}

\section{Graduation from Post-Secondary Education}

Our graduation variable includes students who have graduated from this particular university up to Summer 2018. University graduation rates are tricky to examine as Ontario universities generally do not have a transfer code. Therefore, if students move and subsequently graduate, it is not captured through this data.

\section{Racial Identity}

In this study, racial identities are drawn from a district distributed student survey in which students self-identified as belonging to a particular racial group or a group with which they identify. For this study, we are only reporting the four largest racial groups: Black, East Asian, South Asian, and white.

\section{Program of Study (POS) and Streaming}

When students enter Grade 9, they have the option of taking courses across different programs of study. Program of study refers to courses taken in Grades 9-10 at the Academic, Applied, and Locally Developed level. The program of study into which a student is placed or enrolled is referred to as academic streaming.

\section{Direct and Indirect Pathways to Post- Secondary Education}

Students arrive at university following a number of different pathways. Those who leave high school and head directly to university are considered to follow a direct pathway. And those who may have attended another university, college, or pursued other experiences prior to arrival at university, are considered to have pursued an indirect pathway. 


\section{Table 1}

\section{Description of the Sample}

\begin{tabular}{|c|c|c|c|}
\hline & & $\mathrm{N}$ & $\%$ \\
\hline \multirow[t]{2}{*}{ Gender } & Female & 6668 & 58.4 \\
\hline & Male & 4747 & 41.6 \\
\hline \multirow[t]{8}{*}{ Race } & Black & 1130 & 12.1 \\
\hline & East Asian & 1527 & 16.3 \\
\hline & Latinx & 153 & 1.6 \\
\hline & Middle Eastern & 726 & 7.8 \\
\hline & Mixed & 456 & 4.9 \\
\hline & South Asian & 2566 & 27.5 \\
\hline & South East Asian & 410 & 4.4 \\
\hline & White & 2363 & 25.3 \\
\hline \multirow[t]{4}{*}{ Parent Education } & High School & 1285 & 14 \\
\hline & College & 1552 & 16.9 \\
\hline & University & 4408 & 48.1 \\
\hline & Don’t Know & 1927 & 21 \\
\hline \multirow[t]{4}{*}{ Family Structure } & Two parents & 7378 & 79.7 \\
\hline & Mother Only & 1514 & 16.4 \\
\hline & Father Only & 154 & 1.7 \\
\hline & Other & 209 & 2.3 \\
\hline \multirow[t]{2}{*}{ High School Program } & Academic & 10047 & 88 \\
\hline & Applied & 1285 & 11.3 \\
\hline \multirow[t]{5}{*}{ Pathway to PSE } & Direct to School & 6943 & 60.8 \\
\hline & Other Uni then School & 961 & 8.4 \\
\hline & College then School & 748 & 6.6 \\
\hline & Applied then School & 968 & 8.5 \\
\hline & $\begin{array}{l}\text { Did not apply directly then } \\
\text { School }\end{array}$ & 1794 & 15.7 \\
\hline \multirow[t]{2}{*}{ Graduation } & PSE Graduation & 4530 & 39.7 \\
\hline & No PSE Graduation & 6885 & 60.3 \\
\hline
\end{tabular}

Note. Not all subcategories will add up to 11,417 as students responded differently to different questions related to demographic information and some categories had to be surpressed due to low case counts. 


\section{Gender}

Collected through the school district's administrative data, the gender variable at the time only included male and female. Now, the school district collects multiple gender identities through a student survey.

\section{Family Structure}

Collected through a student survey, this variable indicates students' access to their parents, but does not necessarily indicate which parent or with whom students live. The options here are access to two parents (they do not have to live together), mother only, father only or other. We have reported the percentage of students who have access to two parents.

\section{Parental Education}

This variable includes students' reported highest level of education of their parents. Options include university, college, high school, or "don't know." We have reported the percentage of students whose parents have attended university.

\section{Findings}

Linking the school district and university dataset, we will discuss who entered and graduated from the university, as well as examine their academic trajectories through the public school system, noting how Black students compare with their white and other racialized counterparts. And given that race intersects with other identity characteristics to influence the schooling trajectory of Black students, we have included generational status and region or place of birth (e.g., Canada, Africa, the Caribbean). Often used as a signifier of Canadian identity or Canadianness, examining the intersectional nature of these variables shows how the intersection of generational status and race mediate the educational trajectory of students.

\section{Thinking About Secondary School}

This dataset only includes students who have successfully completed high school and have enrolled in university. In so doing, we aim to ascertain the relationship between high school education and university graduation. Our findings show that, regardless of having entered university, a very strong relationship continues to exist between students' secondary school program of study and academic success as measured by university graduation. Overall, as Table 1 shows, $62.5 \%$ of students who had pursued the Academic Program of Study in secondary school graduated from university. This was true for only 44\% of students who had pursued the Applied Program of Study. For Black youth who entered university having pursued the Academic Program of Study, 53.1\% graduated compared to $66.4 \%$ of East Asian students, $65 \%$ of white students, and $64 \%$ of South Asian students. However, for students who had pursued the Applied Program of Study in secondary school, the drop in graduation rate was quite notable. Of students who had pursued Applied, university graduation rates ranged from $35.6 \%$ of Black students, $48.1 \%$ of South Asian students, $50.9 \%$ of white students, and $55.4 \%$ of East Asian students.

Looking further at Black students' region of birth, a similar relationship between secondary programming and university graduation emerged. Table 2 indicates that, of students who took the Academic level program in high school, Black students born in Africa (55.3\%) were slightly more likely to graduate from university than Canadian-born Black students (52.1\%). However, of students who took the majority of their high school courses at the Applied level, African-born Black students were notably more likely to graduate (44.2\%).

\section{Pathways to University}

In addition to the program of study in secondary school, how students enter university is critically important. Their direct or indirect pathway to university (i.e., first enrolling in other universities, colleges, or pursuing other experiences) has a strong relationship with university graduation. Table 3 shows that students who entered university directly from high school tended to graduate at higher rates than those who took a more indirect route to university. The differences in graduation rates are significant in terms of racial identification. For instance, Black students were least likely (56.7\%) to enter the university directly, while Black students who took an indirect path-just over one-third (37.0\%)—graduated from university.

The relationship between pathway and graduation rates for Black students was exacerbated further when we examine these rates by their region of birth. Interestingly, African-born Black students, as Table 3 


\section{Table 2}

Secondary Programming and University Graduation Rates across Racial Identity

\begin{tabular}{lccccc}
\hline \multicolumn{1}{c}{ Variable } & Black & East Asian & South Asian & White & Student Pop \\
\hline Grad Rates (Overall) & $49.6 \%$ & $65.2 \%$ & $62.3 \%$ & $64.2 \%$ & $60.8 \%$ \\
Academic & $53.1 \%$ & $66.4 \%$ & $64.0 \%$ & $65.0 \%$ & $62.5 \%$ \\
Applied & $35.6 \%$ & $55.4 \%$ & $48.1 \%$ & $50.9 \%$ & $44.0 \%$ \\
\hline
\end{tabular}

Table 3

Black Students' Birthplaces, Secondary School Programs and University Graduation Rates

\begin{tabular}{lcccc}
\hline \multicolumn{1}{c}{ Variable } & Canada & Caribbean & Africa & Total Black Pop \\
\hline Academic & $52.1 \%$ & $47.4 \%$ & $55.3 \%$ & $53.1 \%$ \\
Applied & $33.3 \%$ & - & $44.2 \%$ & $35.6 \%$ \\
\hline
\end{tabular}

Table 4

Pathways to University and University Graduation Rates by Students' Racial Identity

\begin{tabular}{lcc|ccc}
\hline \multicolumn{2}{c|}{ Of Black students who arrive to University } & \multicolumn{3}{c}{ University Graduation rates } \\
\hline Racial Identity & Indirect Pathway & Direct Pathway & Indirect Pathway & Direct Pathway & Overall \\
\hline Black & $43.3 \%$ & $56.7 \%$ & $37.0 \%$ & $59.3 \%$ & $49.6 \%$ \\
East Asian & $29.6 \%$ & $70.4 \%$ & $51.3 \%$ & $70.9 \%$ & $65.2 \%$ \\
South Asian & $32.3 \%$ & $67.7 \%$ & $47.3 \%$ & $69.5 \%$ & $62.3 \%$ \\
White & $37.0 \%$ & $63.0 \%$ & $53.4 \%$ & $70.6 \%$ & $64.2 \%$ \\
Overall & $35.3 \%$ & $64.7 \%$ & $47.2 \%$ & $68.2 \%$ & $60.8 \%$ \\
\hline
\end{tabular}

indicates, were least likely to enter the university via a direct pathway (47.9\%) but were the most likely to graduate $(65.0 \%)$-compared to their Caribbean-born peers whose indirect path to university meant that fewer-just over a quarter (27.8\%) —of them graduated.

\section{Graduation Rates across a Combination of Secondary and Post-Secondary Pathways}

As both secondary school programs and pathways to university have strong relationships with university graduation, we examined the extent to which combining both pathway variables would relate to university graduation. When we combined enrolment in secondary programs 
Table 5

Pathways to University and University Graduation Rates for Black Students by Birthplace

\begin{tabular}{lcc|ccc}
\hline \multicolumn{2}{c|}{ Of Black students who arrive to University } & \multicolumn{3}{c}{ University Graduation rates } \\
\hline Region of Birth & Indirect Pathway & Direct Pathway & Indirect Pathway & Direct Pathway & Overall \\
\hline Canada & $40.0 \%$ & $60.0 \%$ & $34.7 \%$ & $57.8 \%$ & $48.5 \%$ \\
Caribbean & $50.0 \%$ & $50.0 \%$ & $27.8 \%$ & $58.3 \%$ & $43.1 \%$ \\
Africa & $52.1 \%$ & $47.9 \%$ & $42.0 \%$ & $65.0 \%$ & $53.0 \%$ \\
$\begin{array}{l}\text { Overall for Black } \\
\text { Population }\end{array}$ & $43.3 \%$ & $56.7 \%$ & $37.0 \%$ & $59.3 \%$ & $49.6 \%$ \\
\hline
\end{tabular}

with pathways to university, a clear relationship to university graduation across all racial groups can be observed. Particularly, Table 6 and Figure 1 indicate that students who entered university via a direct pathway had higher graduation rates than students who entered via an indirect pathway regardless of program of study in secondary school. Black students who took Academic courses in high school and entered university via a direct path had a graduation rate of $60.9 \%$ compared to a graduation rate of $45.7 \%$ for students who also entered directly but took the majority of their Grade 9-10 courses at the Applied level. For Black students who entered indirectly, there was also a notable difference in university graduation rates in that less than a third of those who took Applied courses (30.3\%) successfully graduated from university.

Figure 1, which follows, provides a visualization of the relationship between education pathways and university graduation noting the identified secondary programming and university pathway factors related

\section{Table 6 \\ Table 6}

University Graduation Rates: Secondary Programs and University Pathway by Students' Race

\begin{tabular}{lccccc}
\hline \multicolumn{1}{c}{ Variable } & Black & East Asian & South Asian & White & Student Pop \\
\hline Direct + Academic & $60.9 \%$ & $71.8 \%$ & $70.7 \%$ & $71.1 \%$ & $69.2 \%$ \\
Direct + Applied & $45.7 \%$ & $63.6 \%$ & $53.3 \%$ & $54.2 \%$ & $55.4 \%$ \\
& & & & & \\
Indirect + Academic & $40.1 \%$ & $52.5 \%$ & $48.0 \%$ & $53.9 \%$ & $49.4 \%$ \\
Indirect + Applied & $30.3 \%$ & $44.9 \%$ & $43.4 \%$ & $48.5 \%$ & $37.5 \%$ \\
\hline
\end{tabular}

to university graduation for Black students. The initial data point includes the $49.6 \%$ overall university graduation rate for Black students. When secondary school programs were added, we begin to see the initiation of divergent trajectories. Black students who took the Academic Program of Study (POS) in high school graduated at a rate of $53.1 \%$ compared to a graduation rate of $35.6 \%$ for Black students who took applied. Overall, for Black students who entered university via a direct pathway, $59.3 \%$ graduated compared to $37 \%$ of those who entered indirectly from high school. The final data point shows a combination of factors. Black students who took both the Academic Program of Study in high school and entered university via a direct pathway, their graduation rate was $60.9 \%$. Conversely, Black students who took the Applied POS in high school and entered university via an indirect pathway, had a graduation rate of $30.3 \%-$ this is half of their peers who took the Academic POS and direct path to university. (See Figure 1.) 
Figure 1

Graduation Rates for Black Students across Secondary to Post-Secondary Pathways

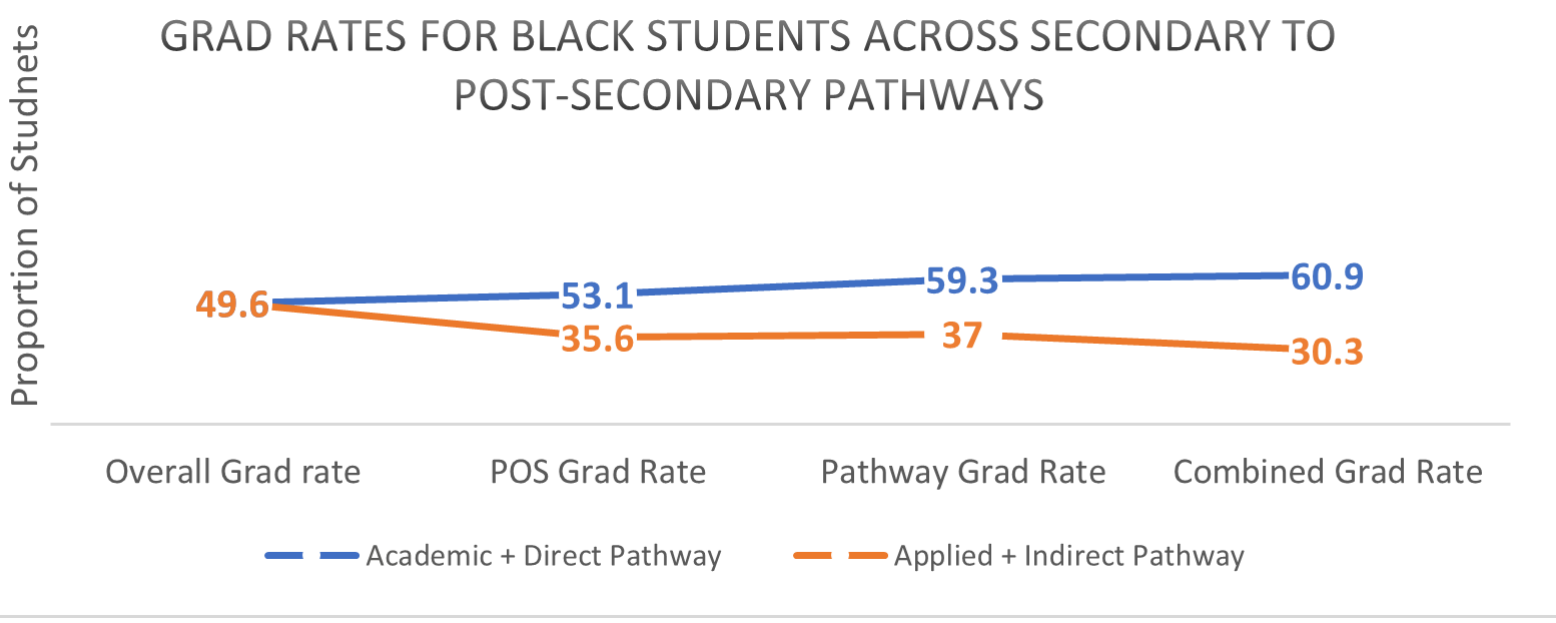

Table 7 shows how the relationship between secondary school program of study and university pathway-in relation to university graduation trends-continues for Black students according to region of birth.

\section{Binary Logistic Regression Analysis}

Following the descriptive statistical results, we queried which of the studied variables was most significant and predictive of university graduation. Therefore, we employed a binary logistic regression. It can be noted that the Hosmer and Lemeshow Test resulted in a significance of 0.472 indicating that the model was a good fit.

The results of the binary regression analysis demon-

\section{Table 7}

University Graduation, Secondary Programs, University Path and Black Students' Birthplace

\begin{tabular}{lcccc}
\hline \multicolumn{1}{c}{ Variable } & Canada & Caribbean & Africa & Black Student Pop \\
\hline Direct + Academic & $59.6 \%$ & $61.3 \%$ & $65.6 \%$ & $71.1 \%$ \\
Direct + Applied & $41.7 \%$ & - & - & $54.2 \%$ \\
& & & & \\
Indirect + Academic & $37.9 \%$ & - & $43.8 \%$ & $53.9 \%$ \\
Indirect + Applied & $28.7 \%$ & - & $36.7 \%$ & $48.5 \%$ \\
\hline
\end{tabular}

strate that, in terms of racial identity, Black students face the most significant barriers in reaching university graduation. When specifically examining racial identity, Black students are significantly less likely to reach graduation across all three regression models. All variables associated with academic streaming in secondary school and pathways to university were also significant. Gender and parents' education also emerged as important contextual factors related to university graduation. In fact, gender (male) and how students arrived at university appear to predict the greatest barriers to university graduation. However, family structure seemed not to have significant predictive value. 


\section{Table 8}

Results of Binary Logistic Regression

\begin{tabular}{lccc}
\hline & Model 1 & Model 2 & Model 3 \\
\hline Independent variables & & & \\
\hline Var 1: Racial identity & & & $0.64^{*}$ \\
Black & $0.55^{*}$ & $0.618^{*}$ & 1.132 \\
East Asian & 1.043 & 0.984 & 0.954 \\
South Asian & 0.922 & 0.908 & reference \\
White & reference & reference & \\
\hline Var 2: Streaming & & reference \\
Academic & & reference & $0.675^{*}$ \\
Applied & & $0.635^{*}$ & \\
\hline Var 3: Pathways & & reference \\
Direct to this Uni & & reference & $0.642^{*}$ \\
Other Uni then School & $0.662^{*}$ & $0.53^{*}$ \\
College then School & $0.514^{*}$ & $0.355^{*}$ \\
Applied then School & $0.344^{*}$ & $0.37^{*}$ \\
Did not apply directly then & $0.348^{*}$ & \\
School & & &
\end{tabular}

Control variables

Var 4: Gender

Female reference

$\begin{array}{lr}\text { Male } & 0.564^{*}\end{array}$

Var 5: Parent Education

$\begin{array}{lc}\text { High School } & 0.818^{*}\end{array}$

$\begin{array}{lr}\text { College } & 0.886\end{array}$

University reference

Don't Know $\quad 0.761^{*}$

Var 6: Family Structure

Two Parents

reference

Mother Only

0.871

Father Only

0.765

Other

0.771

${ }^{*}$ Variables significant at $P<.01$ 


\section{Discussion}

The findings from this study provide useful insights, not only into the pathways to post-secondary education for students of a Southern Ontario School Board, but also into those students who were able to attain the necessary credentials for future high-skills occupations (Government of Canada, 2017); achieving and maintaining good health (Case \& Deaton, 2020) and, ultimately, social and economic mobility. While racial backgrounds, region of birth, and high school program of study may inform the university pathways of students-and hence their educational trajectories-the data show that these factors interact in varying ways to shape individuals' educational and employment opportunities that are supported by existing social and economic structures. As such, the findings reveal the extent to which the students' schooling and educational outcomes are a result of them being sorted and positioned into categories that reproduce the inequity in education based on racial, gender, and cultural background characteristics (Collins, 2009; Domina et. al., 2017)-thereby representing a feature of the Canadian schooling system (Clandfield et al., 2014; James, 2021; Parekh et al., 2020). And as the principles of QuantCrit holds, these findings about the students' educational trajectories point to the ways in which the educational system served them.

The data show that, compared to South Asian, East Asian, and white students, Black students are least likely to graduate. When we consider what might account for Black students' lower rate of graduation from university, the regression analysis indicates that systemic factors such as secondary school program of study, arriving to university via an indirect pathway, and parents' level of education tend to play important roles. Further, the high school progam of study in which Black students are engaged, is directly related to their educational outcomes, and is consistent with Canadian and US studies that have shown that Black students are more likely to be streamed into lower academic programs in high school (Oakes, 2008; James, 2021; Parekh, 2013). This study demonstrates how systemic racism has led to the intergenerational exclusion of Black students, possibly explaining low post-secondary access of Black students and their families. Additionally, Black students are also more likely to enter university via an indirect pathwaypossibly a result of having to engage in further studies before being eligible to apply for university, or financial barriers that might occur when families are systematically excluded from high-skills employment opportunities.

When students are accepted to attend university, the opportunity to enroll is very much perceived as an opportunity to increase social and economic mobility. "Getting in" to university is, in itself, typically a celebrated feat. Regardless of students' earlier experiences in school or how they managed to get to university, getting in represents a fresh start and a recognized opportunity for them to pursue their interests and passions, develop important skills, and expand their critical understandings of the world. But is this so? Is entrance to university the mediator of earlier inequities? Sadly, our study suggests that this is not the case since legacy factors, such as secondary school program of study and pathways to university, are still significant predictors of who graduates. This finding has important policy implications in terms of how best to support students at the secondary level as well as throughout their transition to and life in post-secondary education. The fact is, insofar as higher education becomes an important requirement for young people to attain social and economic stability and mobility, it is important to look outside traditional methods of education and schooling and develop policies and practices that will work to make for a more equitable and inclusive education system. To this end, addressing the particular needs, interests, and aspirations of racialized students-particularly Black students-must be an aim of educators and policy makers noting how education is funded, understood, discussed, and provided.

Insofar as Black students face inordinate and significant structural barriers in reaching university-including being streamed into non-Academic program in high school (James, 2021) -it is understandable that they would be more likely to arrive at university via an indirect pathway, which would have a negative impact on their chances of university graduation. However, the students in this study were all accepted into university; hence, they were deemed to have the potential to successfully complete their program of study, but they were not all equally successful in completing university. While all students may have arrived at university with the drive to succeed, they are likely to have encountered institutional barriers that operated to thwart their educational ambitions. The results of this study indicate that while Black students were able to enter the university, compared to their white and other racialized peers, they 
were less likely to complete university. The reasons may have been due to inadequate support, or they may have encountered the harmful notion of fit. The idea of who fits into a university context, and particular university programs, is communicated to members of the society through media, instructional practices, and the relevance and relatedness of courses to students' needs, interests, expectations, and desires.

While there has been extensive research on how K-12 schooling produces inequity, lesser attention has been paid to the conditions within universities, that either enable or disable the participation and retention of Black students. For instance, in a recent study of student demographics across programs within the studied university, it was found that significant discrepancies exist, particularly across the university's more elite programs. Elite programs, such as business, law, and engineering, have considerably smaller proportions of Black students than general programs in the arts and health (Parekh, Brown, \& James, 2021). In addition to the stratification across programs, how are universities ensuring that students within the institution have access to professors, mentors, and instructors that reflect their own identity? How are the courses shaped to reflect the racial diversity of the school, and how are diverse histories and experiences interwoven into the curricular and experiential opportunities afforded students in the university? What types of leadership opportunities are made available for Black students, and through what venues do they have opportunities to exercise their voices and visions for their education?

Further, Black students' differences in terms of generational status, immigration histories, and region of birth all contribute to their social, cultural, and educational experiences, access to university, and academic outcomes. These experiences and acheivements are also influenced by where the students live, and where they attended high school, as well as the type of education they received, and level of family income. It is noticeable that across all racial categories, Black students were more likely to be born in Canada, but their longstanding lives in Canada tend not to have had a positive effect on their educational performance-a piece of evidence that point to the institutional racism and discrimination that have long characterized the lives of Black Canadians (James, 2021). While intra-generational differences might help explain the educational engagement and trajectories among Black students; so too inter-generatuonal differences likely account for the differences in educational trajectories of Black students and their other racialized peers.

Gender, as in other studies, was shown to play a significant role in the university graduation of students (Briggs, 2021; George, 2020; Goings et al., 2017; McPherson, 2020; Strayhorn, 2017). In fact, gendermore specifically, being identified as male-was a significant predictor of not graduating from university. Besides, across every single outcome of descriptive measures reported in this study, female students outperformed their male counterparts. The connection between gender and graduation was particularly notable for Black students. Of students who graduated from university, $73 \%$ were female. This was also true for close to $81 \%$ of Black students born in the Caribbean. But why? Further research (especially collecting qualitative data) would be useful to ascertain what accounts for the Black young women's engagement in their secondary schooling that would lead to their much better university educational outcomes. At the same time, it would be beneficial to look further at gender, ability or disability, parental or family characteristics, and educational attainment.

Essentially, the findings point to the ways in which, as Domina et al. (2017) point out, educational categories based on biased notions of meritocracy or ability get created and, in turn, serve to influence categorical membership within student populations, hence resulting in the co-construction of both academic and racial categories. As well, the organization of students across educational categories helps to shape their conception of, and experiences with, race and constructed racial boundaries. Furthermore, the institutional acceptance of categorical and racial inequity in $\mathrm{K}-12$ schools, and the stratification of opportunities students are later afforded, serve to shape their social and cultural reproduction, and in turn their outcomes (Bourdieu, 1973). Additionally, as Archer et al. (2018) assert, the form of categorical inequality that racialized and working class students experience holds symbolic violence, particularly since their marginalization within the school system is constructed as "natural" and "deserved" (see also Duncan-Andrade \& Morrell, 2008). The fact is, institutionalized categorical inequality is maintained by the stratified social, racial, and economic pathways that young people experience in their early schooling, which in turn shape their access 
to post-secondary education and employment opportunities and, ultimately, their social and economic outcomes.

\section{Conclusion}

The findings highlight the critical role that secondary school program of study, pathway (direct or indirect) to university, identity characteristics, cultural backgrounds, and family characteristics all play in students' access to a university education and eventual graduation from university. The findings also point to the fact that, despite the growing racially diverse student population and universities' claims of being inclusive, the whiteness and the colonial structure of the university remains. This reality is a reflection of the categorial inequality that is embedded in Canadian society. As such, secondary and post-secondary education systems operationalize and reproduce inequitable social and cultural stratification by structuring opportunities and determining what is possible for students based on their backgrounds and lived experiences. As such, systemic racism, and anti-Black racism in particular, are likely to continue to affect these students' pursuit of a university education.

Given that Black youth's presence as university students is often in question and their lived experiences and histories are not typically recognized or included in university courses or curriculum materials, they are likely to experience an alienating university context, which could contribute to disengagement from their university studies. This situation is likely to be exacerbated by lack of access to needed supports, interventions, and mentorship opportunities offered through various programs and faculties at the university. As well, university programs that fail to reach Black students or connect to their lived experiences may further contribute to questions about the worth of a degree. For some Black students, this lack of relevance or connection with their program of study may make it more difficult for them to see how they might give back to their community (Strayhorn, 2017) leading to resignations based on the futility, impracticality, and/ or hopelessness of their educational efforts.

If differences in educational attainment, as influenced by structured opportunity, are to be addressed, then the social and cultural disparities within higher educational institutions must change toward making these institutions more accessible, inclusive, and equitable; taking into consideration the interlocking roles played by policies, research, teaching, and practices. It is imperative that we not only address university access and choice, but also ensure that concerns pertaining to stratification in higher education be addressed. As this study has shown, Black students do not graduate at similar rates as their counterparts. This may be directly related to the inordinate barriers many students have faced through out their $\mathrm{K}-12$ schooling as well as continue to face in negotiating and navigating the university. It is imperative that educators and administrators adopt multipronged approaches to address the outcomes from intergenerational academic exclusion experienced by many Black students (James, 2021). For as the findings indicate, as a heterogenous group, Black studentsborn in Canada, the Caribbean, and Africa-experience university differently, and gender plays a key role in their schooling and university graduation outcomes.

Significant to our understanding of the pathways and outcomes of these university students is the fact that the institutions (high school and university) they attended, their educational program of study, their direct or indirect path to university, and the meritocractic processes in which they engaged to gain their credentials are all part of an inequitable societal structure that not only categorizes students, but also systemically operates to maintain itself (Domina et al., 2017). In doing so it produces and reproduces the outcomes in which students find themsleves. Essentially, their educational pathways cannot be explained solely by the individual efforts of students or by the credential opportunities that schools and the university provide. In fact, research examining access to post-secondary education is showing that when the playing field is levelled (e.g., analyses that account for economic and structural inequity), Black students tend to fare better than white students in reaching post-secondary education (Parekh, Brown, \& Abdulkarim, 2021). Therefore, to promote students' academic success at the post-secondary level, post-secondary institutions must respond to the social, economic, and cultural conditions of the students they purport to serve.

The reality is, if education for Black and other students is to compensate for, and not re-inscribe, racial, gender, class, and ethnic inequities, as well as status-differentiated social and educational outcomes (Domina et al., 2017), then the ideologies, expectations, norms, and practices-in short, the culture-of educational institu- 
tions must shift to become equitable;paying attention to the differences in the lived experiences of students. And, given that the cultures of educational and other institutions are structured by, and hence interlock with, that of the society, then for the desired systemic changes to come about necessitates bringing into existence a society in which barriers to education are actively addressed and removed.

\section{Acknowledgements}

This study was made possible thanks to the support of the Jean Augustine Chair in Education, Community and Diaspora, the Canada Research Chair in Disability Studies in Education, and through the data support of Dr. Robert S Brown and Dr. David Cameron, Adjunct Professors, York University; and Research \& Development, Toronto District School Board.

\section{References}

Archer, L., Francis, B., Miller, S., Taylor, B., Tereshchenko, A., Mazenod, A., Pepper, D., \& Travers, M-C. (2018). The symbolic violence of setting: A Bourdieusian analysis of mixed methods data on secondary students' views about setting. British Educational Research Journal, 44(1), 119-140. https:/l doi.org/10.1002/berj.3321

Ben-Moshe, L., Chapman, C., \& Carey, A. (Eds.). (2014). Disability incarcerated: Imprisonment and disability in the United States and Canada. Palgrave-MacMillan.

Bhattacharya, T. (2017). Introduction: Mapping social reproduction theory. In T. Bhattacharya (Ed.), Social reproduction theory: Remapping class, recentering oppression (pp. 1-20). Pluto Press. https://www. jstor.org/stable/j.ctt1vz494j

Bourdieu, P. (1973). Cultural reproduction and social reproduction. In R. Brown (Ed.), Knowledge, education, and cultural change (pp. 71-112). Tavistock.

Brantlinger, E. (2006). Who benefits from special education? Remediating (fixing) other people's children. Lawrence Erlbaum Associates.

Briggs, A.Q. (2021). Getting a foot in the door: A critical anti-race analysis of underemployed second generation Caribbean Black male youth. Education, Citizenship and Social Justice, 16(2), 165-179. https://doi.org/10.1177/1746197920909051

Case, A., \& Deaton, A. (2020). Life expectancy in adulthood is falling for those without a BA degree, but as educational gaps have widened, racial gaps have narrowed. PNAS, 118(11), 1-6. https://doi. org/10.1073/pnas.2024777118

Clandfield, D., Curtis, B., Galabuzi, G. E., Gaymes San Vincente, A., Livingstone, D., \& Smaller, H. (Eds.). (2014). Restacking the deck: Streaming by class, race, and gender in Ontario schools. Our Schools/ Our Selves.

Collins, J. (2009). Social reproduction in classrooms and schools. Annual Review of Anthropology, 38, 33-48. https://doi.org/10.1146/annurev.anthro.37.081407.085242

Connor, D. J. (2017). Who is responsible for the racialized practices evident within (special) education and what can be done to change them? Theory Into Practice, 56(3), 226-233. https://doi.org/10.1080/00 405841.2017.1336034

Crenshaw, K. (1989). De-marginalizing the intersection of race and sex: A Black feminist critique of anti-discrimination doctrine, feminist theory and anti-racist policies. University of Chicago Legal Forum, 1989(1), 139-162. https://chicagounbound.uchicago. edu/cgi/viewcontent.cgi?article=1052\&context=uclf

Curtis, B., Livingstone, D. W., \& Smaller, H. (1992). Stacking the deck: The streaming of working class kids in Ontario schools. James Lorimer \& Company.

D'Ignazio, C., \& Klein, L. F. (2020). Data feminism. The MIT Press.

Domina, T., Penner, A., \& Penner, E. (2017). Categorical inequality: Schools as sorting machines. Annual Review of Sociology, 43, 311-330. http://dx.doi. org/10.1146/annurev-soc-060116-053354

Duncan-Andrade, J. M. R., \& Morrell, E. (2008). The art of critical pedagogy: Possibilities for moving from theory to practice in urban schools. Peter Lang.

George, R.C. (2020). Holding it down? The silencing of Black female students in the educational discours- 
es of the Greater Toronto Area. Canadian Journal of Education / Revue canadienne de l'éducation, 43(1), 32-58.

Gewirtz, S., \& Crib, A. (2003). Recent readings of social reproduction: Four fundamental problematics. International Studies in Sociology of Education, 13(3), 243-260. https://www.tandfonline.com/doi/ pdf/10.1080/09620210300200112

Gillborn, D., Warmington, P., \& Demack, S. (2018). QuantCrit: Education, policy, 'big data' and principles for a critical race theory of statistics. Race, Ethnicity and Education, 21(2), 158-179. https:/l doi.org/10.1080/13613324.2017.1377417

Giroux, H. A. (2013). America's education deficit and the war on youth. Monthly Review Press

Giroux, H. A. (2014) Neoliberalism's war on higher education. Haymarket Books.

Goings, R. B., Davis, J., Britto, J., \& Greene, D. (2017). The influence of mentoring on the academic trajectory of a 17-year-old Black male college sophomore from the United Kingdom: A single case study. Mentoring \& Tutoring: Partnership in Learning, 25(3), 346-368. https://doi.org/10.1080/13611267.2 $\underline{017.1364853}$

Gould, S. J. (1996). The mismeasure of man. W. W. Norton \& Company.

Government of Canada. (2017). Imbalances between labour demand and supply (2019-2029). http:/l occupations.esdc.gc.ca/sppc-cops/l.3bd.2t.1ilshtmla-eng.jsp?lid=29\&fid=1\&lang=en

Grayson, J. P. (2014). Negative racial encounters and academic outcomes of international and domestic students in four Canadian universities. Journal of International Students, 4(3), 262-278.

James, C. E. (2019). Adapting, disrupting and resisting: How middle school Black males position themselves in response to racialization in school. Canadian Journal of Sociology, 44(4), 373-398. https://doi.org/10.29173/cjs29518

James, C. E. (2021). "Colour matters": Essays on the experiences, education and pursuits of Black youth. University of Toronto Press.
James, C. E., \& Turner, T. (2017). Towards race equity in education: The schooling of Black students in the Greater Toronto Area. York University. https://edu. yorku.ca/files/2017/04/Towards-Race-Equity-in-Education-April-2017.pdf

Johnson, R. M., Strayhorn, T. L., \& Travers, C. S. (2019). Examining the academic advising experiences of Black males at an urban university: An exploratory case study. Urban Education, 1-27. https://doi.org/10.1177/0042085919894048

Kirby, D. (2009). Widening access: Making the transition from mass to universal post-secondary education in Canada. Journal of Applied Research on Learning, 2, 1-17. http://en.copian.ca/libraryl research/jarl/widening/widening.pdf

Krahn, H., \& Barron, G. (2016). Getting a head start: Parental university education and children's educational and employment outcomes. In W. Lehman (Ed.), Education and society: Canadian perspectives (pp. 36-50). Oxford University Press.

Leonardo, Z., \& Broderick, A. (2011). Smartness as property: A critical explorations of intersections between whiteness and disability studies. Teacher College Record, 113(10), 2206-2232. http://www. tcrecord.org/Content.asp?Contentld=16431

Le Penne, S. (2017). Longing to belong: Needing to be needed in a world in need. Society, 54(6), 535-536. https://doi.org/10.1007/s12115-017-0185-y

Lewis-McCoy, R. L. H. (2014). Inequality in the promised land: Race, resources, and suburban schooling. Stanford University Press.

Livingstone, A-M., Celemencki, J., \& Calixte, M. (2014). Youth participatory action research and school improvement: The missing voices of Black youth in Montreal. Canadian Journal of Education / Revue Canadienne de l'éducation, 37(1), 283-307. http:/l www.jstor.org/stable/canajeducrevucan.37.1.283

Long, M. C., Saenz, V., \& Tienda, M. (2010). Policy transparency and college enrollment: Did the Texas top ten parent law broaden access to the public flagships? Annual American Academic Political Social Sciences, 627(1), 82-105. https://doi. org/10.1177/0002716209348741 
Macris, V. (2011). The ideological conditions of social reproduction. Journal for Critical Education Policy Studies, 9(1), 20-46. http://www.jceps.com/wp-content/uploads/PDFs/09-1-02.pdf

McPherson, K. (2020). Black girls are not magic; they are human: Intersectionality and inequity in the Greater Toronto Area (GTA) schools. Curriculum Inquiry, 50(2) 1-19. https://doi.org/10.1080/036267 84.2020 .1729660

Mirowski, P. (2013). Never let a serious crisis go to waste: How neoliberalism survived the financial meltdown. Verso.

Mitchell, D. (2015). Education that fits: Review of international trends in the education of students with special educational need (2nd ed.). University of Canterbury. https://www.education.vic.gov.aul Documents/about/department/psdlitreview Educationthatfits.pdf

Oakes, J. (2008). Keeping track: Structuring equality and inequality in an era of accountability. Teachers College Record, 110(3), 700-712. https://www. tcrecord.org/Content.asp?Contentld=14610

Parekh, G. (2013). Structured pathways: An exploration of programs of study, school-wide, and in-school programs as well as promotion and transference across secondary schools in the Toronto District School Board (Research Report No. 13/14-03). Toronto District School Board.

Parekh, G. (in press). Ableism in education: Rethinking school practices and policies. W. W. Norton \& Company.

Parekh, G., Brown, R. S., \& Abdulkarim, F. (2021). Streaming: Thinking beyond grade 9. York University \& Toronto District School Board.

Parekh, G., Brown, R. S., \& James, C. E. (2020). Who comes to York? Access, participation and graduation trends. York University.

Parekh, G., Brown, R. S., \& James, C. E. (2021). Identity and pathway information across faculties at York University. York University.

Parekh, G., Brown, R. S., \& Zheng, S. (2018). Learning skills, system equity and implicit bias within On- tario, Canada. Educational Policy, 35(3), 395-421. https://doi.org/10.1177\%2F0895904818813303

Reichelt, M., Collischon, M., \& Eberl, A. (2019). School tracking and its role in social reproduction: Reinforcing educational inheritance and the direct effects of social origin. The British Journal of Sociology, 70(4), 1323-1348. https://onlinelibrary. wiley.com/doi/pdf/10.1111/1468-4446.12655

Rollock, N., Gillborn, D., Vincent, C., \& Ball, S. J. (2015). The colour of class :Tthe educational strategies of the black middle classes. Routledge.

Serna, G. R., \& Woulfe, R. (2017). Social reproduction and college access: Current evidence, context, and potential alternatives. Critical Questions in Education, 8(1), 1-16. https://files.eric.ed.gov/fulltext/ EJ1129434.pdf

Sleeter, C. E., \& Grant, C. A. (2011). Race, class, gender and disability in current textbooks. In $\mathrm{E}$. F. Provenzo, A. N. Shaver, \& M. Bello (Eds.), The textbook as discourse: Sociocultural dimensions of American schoolbooks (pp. 183-215). Routledge.

Smaller, H. (2014). Streaming in Ontario schools. In D. Clandfield, B. Curtis, G. E. Galabuzi, A. Gaymes San Vincente, D. Livingstone, \& H. Smaller (Eds.), Restacking the deck: Streaming by class, race, and gender in Ontario schools (pp. 77-112). Our Schools/Our Selves.

Stanton, A., Zandvliet, D., Dhaliwal, R., \& Black, T. (2016). Understanding students' experiences of well-being in learning environments. Higher Education Studies, 6(3), 90-99. https://files.eric.ed.gov/ fulltext/EJ1109954.pdf

Statistics Canada. (2021). Educational attainment and qualifications: Key indicators. https://www150.statcan.gc.ca/n1/en/subjects/education training and learning/educational attainment and qualifications

Strayhorn, T. L. (2017). Factors that influence the persistence and success of Black men in urban public universities. Urban Education, 52(9), 1106-1128. https://doi.org/10.1177/0042085915623347

Thomas, M. (2010). Neoliberalism, racialization, and the regulation of employment standards. In S. Braedley \& M. Luxton (Eds.), Neoliberalism and 
everyday life (pp. 68-89). McGill-Queen's University Press.

Tzanakis, M. (2011). Bourdieu's social reproduction thesis and the role of cultural capital in educational attainment: A critical review of key empirical studies. Educate, 11(1), 76-90. http://www.educatejournal.org/index.php/educate/article/view/251

Vincent, C. (2017). "The children have only got one education and you have to make sure it's a good one": Parenting and parent-school relations in a neoliberal age. Gender and Education, 5, 541-557. https://doi.org/10.1080/09540253.2016.1274387

Vincent, C., Rollock, N., Ball, S., \& Gillborn, D. (2013). Raising middle-class Black children: Parenting priorities, actions and strategies. Sociology, 47(3), pp. 427-442. https://doi. org/10.1177/0038038512454244

Wright, C. Y., Maylor, U., \& Pickup, T. V. A. (in press). Changing the narrative: Young British African and Caribbean men achieving educational success. Routledge.

\section{Contact Information}

Carl E. James

CJames@edu.yorku.ca 